\title{
The Brand Value and its Impact on Sales in Automotive Industry
}

\author{
Margareta Nadanyiova $^{1 *}$, Lubica Gajanova $^{1}$, Dominika Moravcikova ${ }^{1}$ and Judit Olah ${ }^{2}$ \\ ${ }^{1}$ University University of Zilina, Faculty of Operation and Economics of Transport and \\ Communications, Department of Economics, Univerzitna 1, 01026 Zilina, Slovak Republic; Email: \\ margareta.nadanyiova@fpedas.uniza.sk,lubica.gajaniova@fpedas.uniza.sk, \\ dominika.moravcikova@fpedas.uniza.sk \\ ${ }^{2}$ University of Debrecen, Faculty of Economics and Business, Institute of Apllied Informatics and \\ Logistics, Böszörményi út 138, H-4032 Debrecen, Hungary; Email: olah.judit@econ.unideb.hu
}

\section{*Corresponding Author: Margareta Nadanyiova}

\begin{abstract}
The aim of this article is to define the theoretical basis of brand value from the viewpoint of domestic (Slovak) and foreign authors and its impact on sales. This includes a regression and correlation analyses focused on investigate the dependence between the brand value and sales in automotive industry. The basic sources of research were secondary data obtained from worldwide surveys in the form of rankings published by Forbes magazine, annual reports of companies and published professional publications. General scientific methods were applied for the processing of the data, as well as mathematical-statistical methods to evaluate the data collated from the results of regression and correlation analyses and test the linear independence. The results of analyses show that the brand value and sales are linearly dependent, specifically it is medium-strong direct linear dependence. Therefore, the brand value has a direct effect on sales volume.
\end{abstract}

Keywords: Brand, brand value, sales, automotive industry, consumers

\section{Introduction}

The strong brand is one of the most valuable assets of the company and also a very effective tool in a competitive battle. It is very complicated and costly to get customers who are faithful to another established brand [1]. If they know what they can expect from verified branded products, it is challenging to get them to try another brand, even though these products can be even better [2]. This forms a barrier to entry into the market by potential competitors and makes it much more difficult for the current competitors.

The brand value for the consumer lies in the trust in the unmatched quality of the product at a stable price, advantageous purchase, product satisfaction, brand communications with consumers, traditions, customer's associations with a particular brand, the prestige given by using the product and so on. Associations that a consumer deals with in connection with the brand are such an abstract aspect that contributes to the brand value creation and can be both positive and negative. 
The aim of this article is to define the theoretical basis of brand value from the viewpoint of domestic (Slovak) and foreign authors and its impact on sales. This includes a regression and correlation analyses focused on investigate the dependence between the brand value and sales in automotive industry. Based on the results of analyses, we found out that the brand value and sales are linearly dependent, specifically it is medium-strong direct linear dependence. The basic sources of research were secondary data obtained from worldwide surveys (Interbrand, BrandZ Top 100, etc.) in the form of rankings published by Forbes magazine, annual reports of companies and published professional publications. General scientific methods were applied for the processing of the data, as well as mathematical-statistical methods to evaluate the data collated from the results of regression and correlation analyses and test the linear independence.

The issue of the brand value has been researched and analysed by many foreign and domestic authors, and remains actual.

The result of brand building is the potential to represent a certain value for the company. This value is often monetizable because companies invest substantial funding in the creation and management of a brand [3,4]. As a result, this effort leads to increased sales of branded production. Mostly, this element is referred to as the added value of products or services, which is based on how consumers perceive a brand in its price, market share, or the profit rate that the brand produces [5].

Leek and Christodoulides define brand value as the value of goods and services, as well as added value (functional and emotional) from the brand [6].

According to Aaker, the brand value is a set of assets or liabilities linked to a brand's name and symbol that adds to or subtracts from the value provided by a product or service. However, in addition to these standard items, the value of the brand and the company is also made up of extensive intellectual property, goodwill and last but not least, the price of brands that they have in their portfolio [7].

On the above, we can say that brand value is measured by the consumer's willingness to buy or not to buy the brand's products. The measurement of brand value is strongly linked to loyalty and it measures segments starting with loyal users, ending with those who can move to the brand from competitors.

The term brand value is often used interchangeably with the term brand equity (also known as market or consumer equity). Both terms are viewed as synonymous, whether in the academic field or within the practitioners. In our opinion, the definition of brand equity includes the perceived or behavioural value as well as the economic value and can be regarded as an indicator of the success of a brand [8,9]. Brand equity is a set of assets that are associated with a brand in customers' minds. Generally, brand equity indicates a brand's strength (i.e., brand worth). A brand's strength is linked with different brand associations, which allow a brand name to be more successful than non- 
branded products $[10,11]$. The main aspects of brand equity are awareness, loyalty, and quality $[12,13]$.

For marketers, their main purpose is to influence the perception of consumers and their attitude toward a brand, increase the brand value, establish the brand image in consumers' minds and stimulate their actual purchasing behaviour of the brand. All of this consequently increases sales, maximizes market share and develops brand equity.

Over the years, many authors have dealt with the relationship between brand value and sales.

According to Yeboah, companies which create and effectively manage their brand stand to gain more sales in the long run and the focus should not be on immediate impact of branding but its long run impact. Product branding is increasingly important in the phase of increasing competition in product market [14].

Customer satisfaction plays an important role in boosting the sales of goods, hence, in increasing a given enterprise's profits. Brand loyalty and thus brand value significantly affects sales volumes. A branded product helps increase customer value - customers become the embodiment of the brand's promise [15].

\section{Data and Methods}

As part of the science project APVV - Slovak abbreviation of Slovak Research and Development Agency, our study "Integrated model of management support for building and managing the brand value in the specific conditions of the Slovak Republic" investigated the brand value and its impact on business success. We focused on the world's most valuable brands, based on rankings published by Forbes magazine, Interbrand, and BrandZ Top 100, as well as on the Slovak brands.

When customers attach a level of quality or prestige to a brand, they perceive that brand's products as being worth more than products made by competitors, so they are willing to pay more. In effect, the market bears higher prices for brands that have high levels of brand value. Positive brand value increases profit margin per customer because it allows a company to charge more for a product than competitors, even though it was obtained at the same price.

Based on the above, we can claim, that brand value has a direct effect on sales volume because consumers gravitate toward products with great reputations.

Our survey focused on the rapidly developing automotive industry. Automotive companies are constantly coming into the market with new innovative products, to which competitors immediately react by offering substitute products with comparable characteristics. Therefore, it is necessary for a company to strengthen its brand value, which should result in a competitive advantage.

The impact of brand value on sales is very difficult to quantify because sales are affected by many other factors in addition to brand value. 
Our sample included 10 of the most valuable global automotive brands based on the previously mentioned worldwide surveys (Interbrand, BrandZ Top 100, etc.) published in Forbes magazine. We assessed the impact of the brand value set for the year 2018 on sales. In our study, the consistency of input data played a key role in the methodical approach for quantifying brand value.

Table 1 shows the world's most valuable brands in the automotive industry with information about their rank, brand value, change in brand value, brand revenue, and company sales [16].

Table 1 World's most valuable automotive brands. Source: authors according to [16]

\begin{tabular}{rlcccc}
\hline \multicolumn{1}{r}{ Rank } & \multicolumn{1}{c}{ Brand } & $\begin{array}{c}\text { Brand Value } \\
\mathbf{( \$ B )}\end{array}$ & $\begin{array}{c}\text { Change in Brand } \\
\text { Value } \mathbf{( \% )}\end{array}$ & $\begin{array}{c}\text { Brand Revenue } \\
\mathbf{( \$ B )}\end{array}$ & Sales (\$B) \\
\hline 9 & Toyota & 44,7 & 9 & 176,4 & 265,2 \\
\hline 13 & Mercedes-Benz & 34,4 & 18 & 116,9 & 116,9 \\
\hline 20 & BMW & 31,4 & 9 & 86,8 & 114,4 \\
\hline 24 & Honda & 25,5 & 6 & 120,4 & 138,6 \\
\hline 37 & Audi & 14,8 & 5 & 59,1 & 59,1 \\
\hline 42 & Ford & 14,1 & 3 & 149,3 & 159,6 \\
\hline 56 & Chevrolet & 11,5 & 11 & 25,5 & 25,5 \\
\hline 58 & Porsche & 11 & 11 & 20,7 & 20,7 \\
\hline 69 & Lexus & 9,5 & 9,5 & 95,2 & 106,9 \\
\hline 70 & Nissan & 9,4 & 9,4 & &
\end{tabular}

Statistical hypothesis testing is one of the most important statistical inference procedures. The role of statistical inference is to decide on the basis of information from the available choice whether we accept or reject certain hypotheses regarding the basic set. In verifying the correctness or incorrectness we proceeded in accordance with the methodology of statistical hypothesis testing, which consists of the following steps [16]:

1. Formulation of the null hypothesis (H0).

2. Formulation of the alternative hypothesis $(\mathrm{H} 1)$.

3. Determining the level of significance $(\alpha)$.

4. Calculation of test statistics and probability.

5. Decision.

\section{Hypothesis 1}

Hypothesis H0: Between the brand value and the amount of sales in automotive industry there is no statistically significant relationship.

Hypothesis H1: Between the brand value and the amount of sales in automotive industry there is statistically significant relationship.

Significance level $\alpha$ was determined at 0.05 . To calculate the test statistic, we used Microsoft Excel software. 
We evaluated the relationship between brand value and the amount of sales using the Pearson correlation coefficient (PCC), which is a measure of the linear dependence (correlation) between two variables, $x$ and $y$ :

$$
R=\frac{\operatorname{cov}(x, y)}{s_{x} * s_{y}}=\frac{\overline{x y}-\bar{x} * \bar{y}}{\sqrt{\bar{x}^{2}-\bar{x}^{2}} * \sqrt{\bar{y}^{2}-\bar{y}^{2}}}
$$

\section{Results}

Figure 1 shows a graphical representation (scatter plot) of the relationship between a brand value and sales, which we tried to express by means of a linear function.

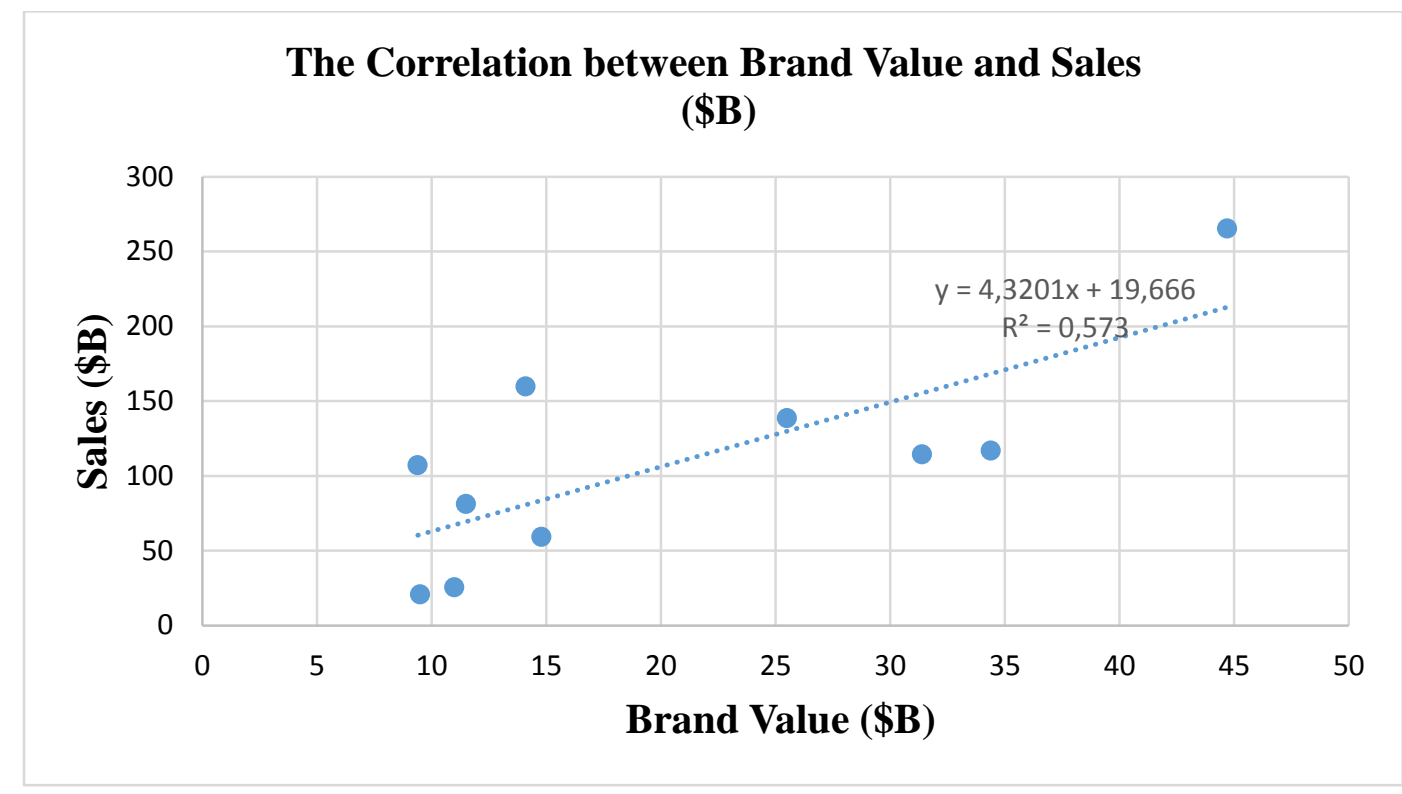

Fig. 1 The Correlation between brand value and sales. Source: authors

Table 2 shows the results of our regression and correlation analysis, which we performed using Data Analysis in Excel.

The PPC value is 0.756950253 , which means that the brand value and sales are linearly dependent, specifically it is medium-strong direct linear dependence. However, it is necessary to verify whether examined parameters are indeed linear dependent or not. For verification, we use the test of linear independence.

We evaluated the degree of causal dependence between the brand value and amount of sales by applying a coefficient of determination, which is defined as the square of the correlation coefficient $\mathrm{R}$. The value of the coefficient of determination in this case is $R^{2}=0,572973686$, which means that $57.30 \%$ of the variance sales is explained by a linear relationship with brand value (regression line). Up to $43.70 \%$ of the variability sales can be explained by other causes, such as a linear relationship between the brand value and sales. 
Table 2 Summary output of regression statistics. Source: authors

\begin{tabular}{|c|c|c|c|c|c|c|c|c|}
\hline \multicolumn{2}{|c|}{ Regression Statistics } & & & & & & & \\
\hline & 0,75695025 & & & & & & & \\
\hline \multirow[t]{2}{*}{ Multiple R } & 3 & & & & & & & \\
\hline & 0,57297368 & & & & & & & \\
\hline R Square & 6 & & & & & & & \\
\hline Adjusted R & 0,51959539 & & & & & & & \\
\hline \multirow[t]{2}{*}{ Square } & 7 & & & & & & & \\
\hline & 49,5378111 & & & & & & & \\
\hline Standard Error & 6 & & & & & & & \\
\hline Observations & 10 & & & & & & & \\
\hline \multicolumn{6}{|c|}{ ANOVA (Analysis of Variance) } & & & \\
\hline \multirow{2}{*}{\multicolumn{2}{|c|}{$\mathrm{df}$}} & SS & MS & $\mathrm{F}$ & $\begin{array}{l}\text { Significance } \\
\mathrm{F}\end{array}$ & & & \\
\hline & & & 2634 & 10,73 & & & & \\
\hline Regression & 1 & 26342 & & 4 & 0,01124964 & & & \\
\hline Residual & 8 & 19632 & 2454 & & & & & \\
\hline \multirow[t]{4}{*}{ Total } & 9 & 45974 & & & & & & \\
\hline & & Standard & & P- & & Upper & Lower & Upper \\
\hline & Coefficients & Error & t Stat & value & Lower 95\% & $95 \%$ & $95,0 \%$ & $95,0 \%$ \\
\hline & 19,6657590 & & & 0,548 & & & & 92,0530 \\
\hline \multirow{2}{*}{ Intercept } & 6 & 31,391 & 0,626 & 5 & $-52,721556$ & 92,05 & $-52,72$ & 74 \\
\hline & 4,32012801 & & & 0,011 & 1,27944124 & & & 7,36081 \\
\hline Brand Value (\$B) & 5 & 1,3186 & 3,276 & 2 & 4 & 7,361 & 1,2794 & 48 \\
\hline
\end{tabular}

The test of linear independence includes the following steps:

1. Determination of the null hypothesis:

$$
H_{0}: R=0
$$

The correlation coefficient is considered to be null, so the variables are linearly independent.

2. Determination of the alternative hypothesis:

$$
H_{1}: R \neq 0
$$

The correlation coefficient is significantly different from zero. Thus, the variables are linearly dependent.

3. Selection of the significance level

$$
\alpha=0,05
$$

4. Application of the test criteria:

$$
T=R \cdot \sqrt{\frac{n-2}{1-R^{2}}}
$$


The test criteria is 3.276310195 .

5. Critical field of the test:

$$
|T| \geq t_{\propto}(n-2)
$$

where $t_{\alpha}(n-2)$ is the critical value of the $t$-distribution at the significance level $\alpha$ with $n-2$ degrees of freedom, to be 2.306004135 .

\section{Decision:}

The inequality applies, so we do not accept the hypothesis H0, we accept the hypothesis H1. Therefore, the correlation coefficient is significantly different from zero and the variables are linearly dependent. It means, that the correlation between brand value and sales exists.

\section{Discussion}

Nowadays, building a strong, competitive position and securing success in market of automotive industry is not at all easy for companies. One of the most effective ways is to promote sales through building strong brand value.

As an example of a successful and strong brand, we can mention Japanese brand Toyota, which is ranked first in the automotive industry in the current ranking of "The World's Most Valuable Brands" 2018 according to Forbes Magazine. Its position is 9th in the overall ranking. The Japanese brand this year is $\$ 44.7$ billion, up 9\% than last year.

For years, Toyota has been one of the top brands in the world. In Forbes Magazine's "The World's Most Valuable Brands". This major success of Toyota in the global automotive market is the result of years of company effort, such as the quality of the produced vehicles, revolutionary technology solutions (e.g. car electrification, hybrid technology and investment in hydrogen fuel cell technology), as well as investment in innovation research, which are changing the perception of automotive industry and are significantly contributing to increasing brand value of Toyota.

\section{Conclusion}

Our results indicate that sales included in our analysis were directly determined by the brand value. The business success in automotive industry and therefore sales volume is therefore significantly dependent on the level of brand value.

In the current competitive environment, it is necessary for companies to improve the value of their brands. Based on our analysis, brand building provides several competitive advantages, which can be summarized as follows:

- increased sales volume and profit; 
- higher margins;

- improved customer loyalty;

- decreased vulnerability to competitive marketing events and crises;

- greater cooperation and support from traders;

- increased effectiveness of marketing communications.

The issue of brand value and its impact of business success such as sales volume has the potential for deeper research in the future - both qualitatively and quantitatively. To obtain statistical relevance, it would be appropriate to investigate the findings of qualitative research quantitatively. A further qualitative investigation would be appropriate for expanding knowledge and comparing the impact of the brand value on sales in other industries, possibly exploring the impact of other factors on sales volume and their comparison.

\section{Acknowledgments}

This paper is an outcome of the science project APVV-15-0505: Integrated model of management support for building and managing the brand value in the specific conditions of the Slovak Republic.

\section{References}

[1] Podhorska, I., Siekelova, A. \& Valaskova, K. (2016). Meaning of the Market Value of Company in the Area of Credit Risk Estimation. In The economies of Balkan and Eastern Europe countries in the changing world - EBEEC 2016, 6-8 May 2016 (pp. 152-157), Split, Croatia.

[2] Lizbetinova, L. (2017). Clusters of Czech Consumers with Focus On Domestic Brands. In 29th International-Business-Information-Management-Association Conference, 3-4 May 2017 (pp. 1703-1718), Vienna, Austria.

[3] Rodrigues, P. \& Martines, F. V. (2016). Perceptual and behavioural dimensions: measuring brand equity consumer based. Journal of Fashion Marketing and Management, 20(4), 507519.

[4] Tringh, G., Romaniuk, J. \& Tanusondjaja, A. (2016). Benchmarking buyer behavior towards new brands, Marketing Letters, 27(4), 743-752.

[5] Wang, Y. L. \& Tzeng, G. H. (2012). Brand marketing for creating brand value based on a MCDM model combining DEMATEL with ANP and VIKTOR methods. Expert systems with applications, 39(5), 5600-5615. 
[6] Leek, S. \& Christodoulides, G. (2012). A Framework of Brand Value in B2B Markets: The Contributing Role of Functional and Emotional Components. In Industrial Marketing Management, 41, 106-114.

[7] Aaker, D. A. (2003). Brand building. Brno: Computer Press.

[8] May, M., Monga, A. B. \& Kalaignanam, K. (2015). Consumer responses to brand failures: the neglected role of honor values. Brand Meaning Management, 12, 257-291.

[9] Van Der Meer, T. G. L. A. (2016). Automated content analysis and crisis communication research, Public Relations Review, 42(5), 952-961.

[10] Valachova, V. \& Kral, P. (2017). Methods for calculating the brand value and its impact on the enterprise value. In: Finance and performance of firms in science, education and practice: proceedings of the 8th international scientific conference, 26-27 April 2017 (pp. 1118-1128), Zlín, Czech Republic.

[11] Gambetti, R. C. \& Ggraffigna, G. (2015). Value co-creation between the "inside' and the "outside' of a company: Insights from a brandcommunity failure. Marketing Theory, 15(2), 155-178.

[12] Kicova E., Kral, P. \& Janoskova, K. (2018). Proposal for brands communication strategy developed on customer segmentation based on psychological factors and decision-making speed in purchasing: case of the automotive industry. Economics and Culture, 15(1), 5-14.

[13] Moravcikova, D. \& Kicova, E. (2018). Brand as a strategic marketing tool of a company in conditions of globalization. In Proceedings of International scientific conference Globalization and its socio-economic consequences 201, 10-11 October 2018 (pp. 755-762), Rajecke Teplice, Slovakia.

[14] Yeboah, M. (2016). Impact of Product Branding on Sales Revenue of Listed Companies in Ghana, International Journal of Academic Research in Business and Social Sciences 2016, 6(9), 112-124.

[15] Zuzek, D. K. (2016). Economic aspects of brand importance affecting the operations and growth of enterprises - research results. In International Scientific Conference on Economic Science for Rural Development, 21-22 April 2016 (186-194), Jelgava, Latvia.

[16] The World's Most Valuable Brands. (2016). Forbes Magazine. Retrieved April 10, 2019, from https://www.forbes.com/powerful-brands/list/.

[17] Rimarcik, M. (2007). Štatistika pre prax. Kosice: Marian Rimarcik. 